\title{
PENGARUH BERAT BENIH DAN MEDIA TANAM TERHADAP PERTUMBUHAN BIBIT KAKAO VARIETAS CRIOLLO (Theobroma cacao L.)
}

\author{
Lukas Pakombong $^{1}$, Puji Astuti ${ }^{2}$, dan Noor Jannah ${ }^{2}$ \\ ${ }^{1}$ Agroteknologi, Fakultas Pertanian, Universitas 17 Agustus 1945 Samarinda, Indonesia. \\ ${ }^{2}$ Dosen Fakultas Pertanian, Universitas 17 Agustus 1945 Samarinda 75124, Indonesia. \\ E-Mail: lukas@untag-smd.ac.id; puji@untag-smd.ac.id
}

\begin{abstract}
ABSTRAK
Pengaruh Berat Benih dan Media Tanam Terhadap Pertumbuhan Bibit Kakao Varietas Criollo (Theobroma cacao L.). Tujuan penelitian untuk mengetahui berat benih dan media tanam serta interaksinya terhadap pertumbuhan bibit kakao, dan juga untuk memperoleh berat benih dan media tanam yang tepat untuk pertumbuhan bibit kakao yang baik.

Penelitian dilaksanakan pada bulan Maret-Juni 2015. Lokasi penelitian di Desa Bukit Harapan, Kecamatan Kaliorang, Kabupaten Kutai Timur, Provinsi Kalimantan Timur.

Penelitian menggunakan dalam Rancangan Acak Lengkap (RAL), percobaan faktorial 3 x 3, dengan 4 ulangan. Terdiri atas 2 faktor perlakuan. Faktor pertama adalah berat benih (B), terdiri atas 3 taraf, yaitu : berat benih 7-13 $\mathrm{g}\left(\mathrm{b}_{1}\right)$, berat benih 14-17 $\mathrm{g}\left(\mathrm{b}_{2}\right)$, dan berat benih 18-20 $\mathrm{g}\left(\mathrm{b}_{3}\right)$. Faktor kedua adalah media tanam (M), terdiri atas 3 taraf, yaitu : tanah top soil + pasir $(1: 1)\left(\mathrm{m}_{1}\right)$, tanah top soil + pupuk kandang sapi $(2: 1)\left(\mathrm{m}_{2}\right)$, dan tanah top soil + sekam padi $(2: 1)\left(\mathrm{m}_{3}\right)$.

Hasil penelitian menunjukkan bahwa perlakuan berat benih berpengaruh sangat nyata terhadap tinggi bibit umur 30, 60, 90 hari setelah tanam, jumlah daun umur 30 hari, umur 60 hari dan umur 90 hari setelah tanam, diameter batang umur 30,60, 90 hari setelah tanam. Bibit tertinggi terdapat pada perlakuan $b_{3}$ (berat benih 18-20 g) yaitu $24,59 \mathrm{~cm}$, sedangkan bibit terendah terdapat pada perlakuan $\mathrm{b}_{1}$ (berat benih 7-13 g) yaitu $23,72 \mathrm{~cm}$.

Perlakuan media tanam berpengaruh sangat nyata terhadap tinggi bibit umur 30, 60, dan 90 hari setelah tanam, jumlah daun umur 30, 60, 90 hari setelah tanam, diameter batang umur 30 hari, umur 60 hari dan umur 90 hari setelah tanam. Jumlah daun terbanyak terdapat pada perlakuan $\mathrm{m}_{3}$ (tanah top soil + sekam padi) yaitu ; 20,64 helai, sedangkan jumlah daun paling sedikit terdapat pada perlakuan $\mathrm{m}_{1}$ (tanah top soil + pasir) yaitu ; 18,22 helai.

Interaksi perlakuan berat benih dan media tanam tidak berpengaruh nyata terhadap tinggi bibit umur 60, 90 hari setelah tanam, jumlah daun umur 90 hari setelah tanam, dan diameter batang umur 60, 90 hari setelah tanam. Berpengaruh nyata terhadap diameter batang umur 30 hari setelah tanam. Berpengaruh sangat nyata terhadap tinggi bibit umur 30 hari setelah tanam, jumlah daun umur 30 hari dan umur 60 hari setelah tanam.
\end{abstract}

Kata kunci : Berat benih, media, kakao, pertumbuhan.

\begin{abstract}
Effect of Seed Weight and Planting Media on the Growth of Criollo Varieties of Cacao (Theobroma cacao L.). The purpose of the study was to determine the weight of seeds and planting media and their interactions with the growth of cocoa seedlings, and also to obtain the right weight of seeds and planting media for growth of good cocoa seedlings.

The study was conducted in March-June 2015. The research location was in Bukit Harapan Village, Kaliorang District, East Kutai Regency, East Kalimantan Province.

The study used a Completely Randomized Design (CRD), a 3 x 3 factorial experiment, with 4 replications. Consists of 2 treatment factors. The first factor is seed weight (B), consisting of 3 levels, namely: seed weight 7-13 g (b1), seed weight 14-17 g (b2), and seed weight 18-20 g (b3). The second factor is the planting media (M), consisting of 3 levels, namely: top soil + sand (1: 1) (m1), top soil + cow manure (2: 1) (m2), and top soil + rice husk $(2: 1)(\mathrm{m} 3)$.

The results showed that seed weight treatment had a very significant effect on seedling height at 30, 60, 90
\end{abstract}


days after planting, number of leaves at 30 days, at 60 days and at 90 days after planting, stem diameter at 30, 60, 90 days after planting. . The highest seedlings were in the b3 treatment (seed weight 18-20 g) which was $24.59 \mathrm{~cm}$, while the lowest seedlings were in the treatment b1 (seed weight $7-13 \mathrm{~g}$ ) which was $23.72 \mathrm{~cm}$. The treatment of planting media had a very significant effect on the height of seedlings aged 30, 60, and 90 days after planting, the number of leaves aged 30, 60, 90 days after planting, stem diameter 30 days old, 60 days old and 90 days after planting. The highest number of leaves is in the treatment of $\mathrm{m} 3$ (top soil + rice husk), namely; 20,64 strands, while the least number of leaves is found in the treatment of $\mathrm{m} 1$ (top soil + sand), namely; 18.22 strands.

The interaction of seed weight treatment and planting media did not significantly affect seedling age at 60, 90 days after planting, number of leaves at 90 days after planting, and stem diameter at 60, 90 days after planting. Significantly affect the diameter of the stem age 30 days after planting. Very significant effect on seedling age 30 days after planting, the number of leaves aged 30 days and age 60 days after planting.

Key words : Seed weight, media, cocoa, growth.

\section{PENDAHULUAN}

Konsumsi kakao setiap tahun selalu meningkat. Karena berbagai kebutuhan industri makanan maupun minuman banyak yang membutuhkan kakao di seluruh dunia. Pengaruh goncangan harga kakao sangat kecil, sebab permintaan cokelat dunia semakin meningkat. Naik-turunnya harga kakao biasanya hanya dipengaruhi adanya perubahan-perubahan iklim.

Konsumsi kakao yan kini tergolong Negara konsumen kakao yang utama diperkirakan oleh FAO akan meningkat sekitar $1,9 \%$ per tahun. Perkiraan ini berdasarkan pada perkembangan penduduk di dunia terutama di negaranegara konsumen.

Masalahnya sekarang adalah "'Apakah produksi kakao yang diragukan masih dapat ditingkatkan untuk memenuhi kebutuhan kakao di seluruh dunia dimasa-masa mendatang. Produksi kakao dunia sebenarnya masih bisa ditingkatkan secara besar-besaran, terutama di Afrika Barat dan Amerika Serikat, jika dilakukan pengembangn lahan untuk perkebunan tanaman kakao.

Prospek tanaman kakao di Indonesia, khususnya di Kalimantan Timur sudah cukup baik, namun saat ini tanaman kakao masih terus dibudidayakan, karena mempunyai nilai komersil yang tinggi. Untuk pengembangan tanaman kakao, perlu diupayakan penyediaan bibit tanaman kakao yang bermutu melalui perbanyakan tanaman secara generatif (melalui biji) dan vegetatif (okulasi dan grafting). Lahan di Kalimantan Timur masih memungkinkan untuk mengembangkan tanaman kakao, karena tersedia masih sangat luas, baik berupa lahan pasca tambang maupun lahan pasca HPH (Hak Pengusahaan Hutan).

Prospek pengembangan tanaman kakao khususnya di Kalimantan Timur secara intensif dalam skala agribisnis atau agroindustri cukup cerah. Hal ini dapat dilihat dari permintaan konsumen pada saat musim panen kakao sangat banyak. Selain itu untuk industri, buah kakao dapat dijadikan sebagai bahan campuran makanan maupun minuman, sehingga mempunyai nilai ekonomi cukup tinggi.

Kendala dalam pengembangan tanaman kakao salah satunya adalah penyediaan bibit. Usaha untuk mengatasi hal tersebut dapat dilakukan melalui teknik penyediaan bibit yang baik. Dalam teknik penyediaan bibit yang baik maka perlu diperhatikan berat biji yang akan digunakan sebagai benih dan juga tidak kalah pentingnya adalah media tanaman untuk pembibitan yang digunakan dalam penelitian.

Benih di dalam penyimpanannya memiliki karbohidrat, protein, lemak dan mineral yang diperlukan sebagai bahan baku dan energy bagi embrio pada saat 
perkecambahan. Diduga bahwa benih yang berukuran besar dan berat mengandung cadangan makan lebih banyak dibandingkan benih yang berukuran kecil, sehingga diharapkan pertumbuhannya lebih baik. Sedangkan bahan campuran untuk media tanam dapat digunakan dari bahan apa saja asalkan dapat dijadikan tempat tumbuh tanaman, Mampu mengikat air dan unsur hara, mempunyai draenase dan aerasi yang baik, dapat mempertahankan kelembaban disekitar akar tanaman, tidak menjadi sumber penyakit dan mudah didapat. Pada penelitian ini menggunakan media dari campuran tanah dan pasir, campuran tanah dengan sekam padi dan campuran tanah dengan pupuk kandang. Berdasarkan uraian tersebut maka dilakukan penelitian dengan judul ", Pengaruh Berat Benih dan Media Tanam Terhadap Pertumbuhan Bibit Kakao (Theobroma cacao L.)'”. Tujuan Peneltian adalah : Untuk mengetahui pengaruh berat benih dan media tanam serta interaksinya terhadap pertumbuhan bibit kakao varietas Criollo. Untuk memperoleh berat benih dan media tanam yang tepat untuk pertumbuhan bibit kakao varietas Criollo yang baik.

\section{METODA PENELITIAN}

2.1. Tempat dan Waktu

Penelitian dilaksanakan di Desa Bukit Harapan, Kecamatan Kaliorang, Kabupaten Kutai Timur, Provinsi Kalimantan Timur. Pada bulan Maret-Juni 2015.

2.2. Bahan dan Alat

Bahan yang digunakan dalam penelitian ini adalah : benih kakao varietas Criollo dari kebun petani dengan ukuran berat 7-13 g, 14-17 g dan 18-20 g, polibag ukuran $20 \mathrm{~cm} \mathrm{x}$ $30 \mathrm{~cm}$, pupuk kandang sapi, tanah top soil, pasir sungai, sekam padi,
Furadan 3 G, fungisida Anfush, insektisida Curacron.

Alat yang dipergunakan adalah : alat tulis-menulis, karung goni, cetok, cangkul, timbangan analitik, kayu balok, paranet, ayakan, kamera untuk dokumentasi penelitian, komputer atau laptop, hand sprayer, meteran dan jangka sorong (mikro kalifer).

\subsection{Metode Penelitian}

Penelitian ini disusun dalam Rancangan Acak Lengkap (RAL) dengan analisis faktorial $3 \times 4$ dengan jumlah ulangan sebanyak 4 kali. Perlakuan terdiri atas 2 faktor, yaitu :

Faktor Perlakuan Berat Benih (B), terdiri atas 3 taraf, yaitu :

$\mathrm{b}_{1}=$ berat benih $7-13 \mathrm{~g}$

$\mathrm{b}_{2}=$ berat benih 14-17 $\mathrm{g}$

$\mathrm{b}_{3}=$ berat benih 18-20 g

Faktor Perlakuan Media Tanam (M), terdiri atas 3 taraf, yaitu :

$\mathrm{m}_{1}=$ tanah top soil $+\operatorname{pasir}(1: 1)$

$\mathrm{m}_{3}=$ tanah top soil + sekam padi

$(2: 1)$

$\mathrm{m}_{2}=$ tanah top soil + pupuk

kandang $(2: 1)$

Kombinasi perlakuannya adalah sebagai berikut :

$\begin{array}{lll}b_{1} m_{1} & b_{2} m_{1} & b_{3} m_{1} \\ b_{1} m_{2} & b_{2} m_{2} & b_{3} m_{2} \\ b_{1} m_{3} & b_{2} m_{3} & b_{3} m_{3}\end{array}$

Terdapat kombinasi perlakuan berat benih dan media tanam serta ulangan sebanyak 4 kali, maka menjadi 3 x 3 $\mathrm{x} 4=36$ unit perlakuan.

\subsection{Pelaksanaan Penelitian \\ Persiapan Bahan Tanam}

Media tanah top soil yang digunakan untuk penelitian diambil dari sekitar tempat penelitian, kemudian dibersihkan dari kotoran dengan menggunakan ayakan. Media pasir yang digunakan berasal dari pasir sungai, 
pupuk kandang sapi diperoleh dari petani peternak sapi yang sudah jadi (pupuk kandang sudah mengalami dekomposisi). Sekam padi diperoleh dengan membeli di penggilingan padi. Media tanam yang digunakan merupakan campuran dari berbagai bahan yang telah ditetapkan sesuai perlakuan. Kemudian dimasukkan ke dalam polibag dengan ukuran $20 \mathrm{~cm} \mathrm{x}$ $30 \mathrm{~cm}$, dan padatkan hingga $90 \%$ volume polibag. Polibag yang telah diisi media tanam, kemudian diletakkan ditempat penelitian sesuai hasil pengacakan perlakuan dengan cara undian. Jarak antar polibag $40 \mathrm{~cm}$.

\section{Persiapan Benih}

Benih berasal dari buah kakao varietas Criollo yang sudah masak dengan warna buah kuning. Buah dipotong $1 / 4$ bagian ujungnya, kemudian bagian tengah diambil bijinya. Biji dibersihkan dengan air dan dipilih yang sehat dan seragam, kemudian dikeringanginkan, lalu dipilih dan dikelompokkan benih berdasarkan berat benihnya sesuai perlakuan, yaitu berat benih antara 7-13 g, 14-17 g dan berat benih 18-20 $\mathrm{g}$.

\section{Penanaman Benih}

Benih kakao di tanam di dalam polibag yang telah disiapkan sesuai dengan perlakuan dengan kedalaman 5 $\mathrm{cm}$, dan tiap lubang di tanam satu benih.

\section{Pemeliharaan}

\section{a. Penyiraman}

Penyiraman dilakukan 2 kali sehari, yaitu pada pagi hari dan sore hari. Apabila tanah di polibag masih basah karena air hujan, maka tidak dilakukan pada hari tersebut.

b. Penyiangan

Penyiangan gulma dilakukan terhadap gulma yang tumbuh, baik di dalam polibag maupun disekitar polibag.

c. Penyulaman
Penyulaman dilakukan apabila ada bibit yang mati atau tidak tumbuh menggunakan bibit cadangan (bibit dengan umur yang sama) pada umur 2 minggu setelah tanam.

2.5. Pengambilan dan Pengumpulan Data Data penelitian yang diamati adalah sebagai berikut :

Tinggi Bibit $(\mathrm{cm})$

Untuk keseragaman pengukuran tinggi, maka pada batang bibit kakao diberi tanda untuk tempat pengukuran dengan kayu. Pengukuran dimulai dari pangkal batang sampai titik tumbuh dengan menggunakan meteran, dilakukan pada umur bibit 30 hari, umur 60 hari dan umur 90 hari setelah tanam.

Jumlah Daun (helai)

Jumlah daun dihitung pada daun yang terbentuk dan telah membuka sempurna pada umur bibit 30 hari, umur 60 hari dan 90 hari setelah tanam

Diameter Batang $(\mathrm{cm})$

Diameter batang bibit kakao diukur dengan cara meletakkan jangka sorong (mikro kalifer) pada bagian pangkal batang yang telah diberi tanda $(\mathrm{cm})$, pada umur bibit 30 hari, 60 hari dan 90 hari setelah tanam.

\subsection{Analisis Data}

Untuk mengetahui pengaruh perlakuan berat benih dan media tanam serta interaksinya terhadap semua parameter penelitian yang diamati atau dikukur, maka menggunakan model Sidik Ragam dalam Rancangan Acak Kelompok (RAL) Faktorial menurut Hanafiah (2003). 
Bila hasil sidik ragam terhadap perlakuan tidak berpengaruh nyata, yang menunjukkan F.hitung $\leq$ F.tabel 5\%, maka tidak dilakukan uji lanjutan, tetapi bila hasil sidik ragam terhadap perlakuan berpengaruh nyata, yang menunjukkan F.hitung $\geq$ F.tabel $5 \%$, atau berpengaruh sangat nyata, yang menunjukkan F.hitung $\geq$ F.tabel 1\%, maka dilakukan uji lanjutan dengan uji Beda Nyata Terkecil (BNT) taraf $5 \%$.

\section{Rumus Umum Uji BNT disajikan} sebagai berikut :

$$
\text { BNT } 5 \%=\text { t-tabel }(\alpha, \mathrm{db}) \quad \mathrm{x}
$$

$\sqrt{2 \mathrm{KT} \text { Galat/rt }}$
Keterangan :

$\begin{array}{lll}\text { t-tabel } & = & \text { nilai t-tabel (sebaran } \\ \text { nilai pada } \mathrm{t}_{\text {tabel }} \alpha & 5 \% & \text { dengan dbnya) } \\ \text { KT galat } & = & \text { kuadrat tengah galat } \\ \mathrm{r} & = & \text { ulangan } \\ \mathrm{t} & = & \text { perlakuan }\end{array}$

\section{HASIL PENELITIAN} PEMBAHASAN

\subsection{Tinggi Bibit Kakao Umur 30 Hari Setelah Tanam}

Hasil sidik ragam menunjukkan bahwa perlakuan berat benih dan media tanam serta interaksinya berpengaruh sangat nyata terhadap tingi tanaman umur 30 hari setelah tanam. Data penelitian dapat dilihat pada Tabel 1.

Tabel 1. Rekapitulasi Data Penelitian Pengaruh Berat Benih dan Media Tanam Terhadap Pertumbuhan Bibit Kakao Varietas Criollo (Theobroma cacao L.)

\begin{tabular}{|c|c|c|c|c|c|c|c|c|c|}
\hline \multirow{2}{*}{$\begin{array}{l}\text { Faktor } \\
\text { Perlakuan }\end{array}$} & \multicolumn{3}{|c|}{ Tinggi Bibit $(\mathrm{cm})$} & \multicolumn{3}{|c|}{ Jumlah Daun (helai) } & \multicolumn{3}{|c|}{ Diameter Batang $(\mathrm{cm})$} \\
\hline & $\begin{array}{c}30 \\
\text { HST }\end{array}$ & $60 \mathrm{HST}$ & $\begin{array}{c}90 \\
\text { HSTi }\end{array}$ & $30 \mathrm{HST}$ & $60 \mathrm{HST}$ & $90 \mathrm{HST}$ & $\begin{array}{c}30 \\
\text { HST }\end{array}$ & $\begin{array}{c}60 \\
\text { HST }\end{array}$ & $\begin{array}{c}90 \\
\text { HST }\end{array}$ \\
\hline $\begin{array}{l}\text { Berat Benih } \\
\text { (B) } \\
\text { Sidik Ragam }\end{array}$ & $* *$ & $* *$ & $* *$ & $* *$ & $* *$ & $* *$ & $* *$ & $* *$ & $* *$ \\
\hline$\left(b_{1}\right)$ & $15,31 \mathrm{c}$ & $17,53 \mathrm{c}$ & $23,72 b$ & $4,36 \mathrm{c}$ & $12,52 \mathrm{c}$ & $17,69 \mathrm{~b}$ & $0,33 \mathrm{c}$ & $0,63 \mathrm{~b}$ & $0,76 \mathrm{~b}$ \\
\hline$\left(b_{2}\right)$ & $\begin{array}{c}15,79 \\
b\end{array}$ & $17,71 \mathrm{~b}$ & $23,86 \mathrm{~b}$ & $4,48 \mathrm{~b}$ & $13,42 \mathrm{~b}$ & $19,53 \mathrm{a}$ & $0,35 \mathrm{~b}$ & $0,63 \mathrm{~b}$ & $0,77 \mathrm{~b}$ \\
\hline$\left(b_{3}\right)$ & $16,22 \mathrm{a}$ & $18,45 \mathrm{a}$ & $24,59 \mathrm{a}$ & $4,85 \mathrm{a}$ & $13,74 \mathrm{a}$ & $20,13 \mathrm{a}$ & $0,36 \mathrm{a}$ & $0,68 \mathrm{a}$ & $0,87 \mathrm{a}$ \\
\hline $\begin{array}{l}\text { Media } \\
\text { Tanam (M) } \\
\text { Sidik Ragam }\end{array}$ & $* *$ & $* *$ & $* *$ & $* *$ & $* *$ & $* *$ & $* *$ & $* *$ & $* *$ \\
\hline $\begin{array}{l}\left(\mathrm{m}_{1}\right) \\
\left(\mathrm{m}_{2}\right) \\
\left(\mathrm{m}_{3}\right)\end{array}$ & $\begin{array}{c}15,47 \mathrm{c} \\
15,66 \\
\mathrm{~b} \\
16,20 \mathrm{a}\end{array}$ & $\begin{array}{l}17,68 \mathrm{~b} \\
18,51 \mathrm{a}\end{array}$ & $\begin{array}{l}23,87 \mathrm{~b} \\
24,69 \mathrm{a}\end{array}$ & $\begin{array}{c}13,42 \mathrm{~b} \\
13,74 \mathrm{a} \\
4,98 \mathrm{a}\end{array}$ & $\begin{array}{l}13,14 \mathrm{~b} \\
13,61 \mathrm{a}\end{array}$ & $\begin{array}{l}18,25 \mathrm{~b} \\
20,64 \mathrm{a}\end{array}$ & $\begin{array}{l}0,77 \mathrm{~b} \\
0,87 \mathrm{a}\end{array}$ & $\begin{array}{l}0,65 \mathrm{~b} \\
0,67 \mathrm{a}\end{array}$ & $\begin{array}{l}0,82 \mathrm{~b} \\
0,85 \mathrm{a}\end{array}$ \\
\hline $\begin{array}{l}\text { Interaksi } \\
\text { (BxM) } \\
\text { Sidik Ragam }\end{array}$ & $* *$ & tn & tn & $* *$ & $* *$ & tn & $*$ & tn & tn \\
\hline $\mathrm{b}_{1} \mathrm{~m}_{1}$ & $\begin{array}{c}15,14 \\
\mathrm{~g}\end{array}$ & 17,15 & 23,37 & $4,14 \mathrm{~d}$ & $12,19 \mathrm{f}$ & 16,24 & $0,30 \mathrm{f}$ & 0,60 & 0,72 \\
\hline $\mathrm{b}_{1} \mathrm{~m}_{2}$ & $\begin{array}{c}15,26 \\
\mathrm{fg}\end{array}$ & 17,25 & 23,54 & $4,28 \mathrm{~cd}$ & $12,29 \mathrm{f}$ & 16,44 & $\begin{array}{l}0,33 \\
\text { cde }\end{array}$ & 0,63 & 0,77 \\
\hline $\mathrm{b}_{1} \mathrm{~m}_{3}$ & $15,53 \mathrm{e}$ & 18,18 & 24,24 & $4,65 \mathrm{~b}$ & $13,09 \mathrm{e}$ & 20,39 & $0,35 \mathrm{c}$ & 0,66 & 0,80 \\
\hline $\mathrm{b}_{2} \mathrm{~m}_{1}$ & $\begin{array}{c}15,42 \\
\text { ef }\end{array}$ & 17,39 & 23,49 & $4,20 \mathrm{~d}$ & $\begin{array}{c}13,24 \\
\text { de }\end{array}$ & 19,17 & $\begin{array}{c}0,32 \\
\text { def }\end{array}$ & 0,61 & 0,72 \\
\hline
\end{tabular}




\begin{tabular}{|c|c|c|c|c|c|c|c|c|c|}
\hline $\mathrm{b}_{2} \mathrm{~m}_{2}$ & $15,57 \mathrm{e}$ & 17,48 & 23,53 & $4,40 \mathrm{c}$ & $\begin{array}{c}13,44 \\
\mathrm{~cd}\end{array}$ & 19,27 & $0,35 \mathrm{~cd}$ & 0,63 & 0,78 \\
\hline $\mathrm{b}_{2} \mathrm{~m}_{3}$ & $\begin{array}{c}16,38 \\
\text { b }\end{array}$ & 18,26 & 24,55 & $4,85 \mathrm{~b}$ & $\begin{array}{c}13,58 \\
\text { bc }\end{array}$ & 20,16 & $0,38 \mathrm{~b}$ & 0,64 & 0,80 \\
\hline $\mathrm{b}_{3} \mathrm{~m}_{1}$ & $\begin{array}{c}15,84 \\
\mathrm{~d}\end{array}$ & 17,92 & 23,94 & $4,32 \mathrm{~cd}$ & $\begin{array}{c}13,36 \\
\mathrm{~cd}\end{array}$ & 19,36 & 0,31 ef & 0,64 & 0,85 \\
\hline $\mathrm{b}_{3} \mathrm{~m}_{2}$ & $16,14 \mathrm{c}$ & 18,32 & 24,54 & $4,78 \mathrm{~b}$ & $13,68 \mathrm{~b}$ & 19,64 & $0,38 a b$ & 0,68 & 0,90 \\
\hline$b_{3} m_{3}$ & $16,69 a$ & 19,10 & 25,28 & $5,45 \mathrm{a}$ & $14,17 \mathrm{a}$ & 21,38 & $0,40 \mathrm{a}$ & 0,72 & 0,95 \\
\hline
\end{tabular}

Keterangan :

$\mathrm{b}_{1}$ : berat benih 7-13 $\mathrm{g}$

$\mathrm{m}_{1}:$ tanah rop soil + tanah

pasir (1:1)

$b_{2}$ : berat benih $14-17 \mathrm{~g}$

$\mathrm{m}_{2}$ : tanah rop soil + sekam

padi (2: 1)

$b_{2}$ : berat benih $18-20 \mathrm{~g}$

$\mathrm{m}_{3}$ : tanah rop soil + pupuk

kandang (2: 1)

HST : Hari Setelah Tanam

Hasil uji BNT taraf $5 \%$ terhadap parameter tinggi bibit umur 30 hari setelah tanam pada perlakuan berat benih (B) menunjukkan bahwa perlakuan $b_{1}, b_{2}$ dan $b_{3}$ satu sama lainnya saling berbeda nyata.

Hasil uji BNT taraf $5 \%$ terhadap parameter tinggi bibit umur 30 hari setelah tanam pada perlakuan media tanam (M) menunjukkan bahwa perlakuan $\mathrm{m}_{1}, \mathrm{~m}_{2}$ dan $\mathrm{m}_{3}$ satu sama lainnya saling berbeda nyata.

Hasil uji BNT taraf $5 \%$ terhadap tinggi bibit pada interaksi perlakuan berat benih dan media tanam (BxM) menunjukkan bahwa perlakuan $b_{3} m_{3}$ berbeda nyata dengan perlakuan $b_{2} m_{3}$, $b_{3} m_{2}, b_{3} m_{1}, b_{2} m_{2}, b_{1} m_{3}, b_{2} m_{1}, b_{1} m_{2}$ dan $b_{1} m_{1}$. Perlakuan $b_{2} m_{3}$ berbeda nyata dengan perlakuan $b_{3} m_{2}, \quad b_{3} m_{1}, \quad b_{2} m_{2}$, $b_{1} m_{3}, b_{2} m_{1}, b_{1} m_{2}$ dan $b_{1} m_{1}$. Perlakuan $b_{3} m_{2} b_{3} m_{1}, b_{2} m_{2}, b_{1} m_{3}, b_{2} m_{1}, b_{1} m_{2}$ dan $b_{1} m_{1}$. Perlakuan $b_{3} m_{1}$ berbeda nyata dengan perlakuan $b_{3} m_{1}$ berbeda nyata dengan perlakuan $b_{2} m_{2}, b_{1} m_{3}, b_{2} m_{1}, b_{1} m_{2}$ dan $b_{1} m_{1}$. Perlakuan $b_{2} m_{2}$ dan $b_{1} m_{3}$ tidak berbeda nayat dengan perlakuan $\mathrm{b}_{2} \mathrm{~m}_{1}$, tetapi berbeda nyata dengan perlakuan , $\mathrm{b}_{1} \mathrm{~m}_{2}$ dan $\mathrm{b}_{1} \mathrm{~m}_{1}$. Perlakuan $\mathrm{b}_{2} \mathrm{~m}_{1}$ tidak berbeda nyata dengan perlakuan $b_{1} m_{2}$, tetapi berbeda nyata dengan perlakuan $\mathrm{b}_{1} \mathrm{~m}_{1}$. Perlakuan $\mathrm{b}_{1} \mathrm{~m}_{2}$ tidak berbeda nyata dengan perlakuan $b_{1} m_{1}$.

\subsection{Tinggi Bibit Kakao Umur 60 Hari Setelah Tanam}

Hasil sidik ragam menunjukkan bahwa perlakuan berat benih dan media tanam berpengaruh sangat nyata, sedangkan interaksinya tidak berpengaruh nyata terhadap tingi tanaman umur 60 hari setelah tanam pada tabel 1 .

Pada perlakuan berat benih (B) menunjukkan bahwa perlakuan $b_{1}, b_{2}$ dan $b_{3}$ satu sama lainnya saling berbeda nyata.

Hasil uji BNT taraf $5 \%$ terhadap parameter tinggi bibit umur 60 hari setelah tanam pada perlakuan media tanam (M) menunjukkan bahwa perlakuan $\mathrm{m}_{1}, \mathrm{~m}_{2}$ dan $\mathrm{m}_{3}$ satu sama lainnya saling berbeda nyata.

\subsection{Tinggi Bibit Kakao Umur 90 Hari Setelah Tanam}

Hasil sidik ragam menunjukkan bahwa perlakuan berat benih dan media tanam berpengaruh sangat nyata, sedangkan interaksinya tidak berpengaruh nyata terhadap tingi tanaman umur 90 hari setelah tanam tabel 1 .

Hasil uji BNT taraf $5 \%$ terhadap parameter tinggi bibit umur 60 hari setelah tanam pada perlakuan media 
tanam (B) menunjukkan bahwa perlakuan $b_{3}$ berbeda nyata dengan perlakuan $b_{2}$ dan $b_{1}$. Perlakuan $b_{2}$ tidak berbeda nyata dengan perlakuan $b_{1}$.

Hasil uji BNT taraf $5 \%$ terhadap parameter tinggi bibit umur 60 hari setelah tanam pada perlakuan media tanam (M) menunjukkan bahwa perlakuan $\mathrm{m}_{1}, \mathrm{~m}_{2}$ dan $\mathrm{m}_{3}$ satu sama lainnya saling berbeda nyata.

\subsection{Jumlah Daun Bibit Kakao Umur 30 Hari Setelah Tanam}

Hasil sidik ragam menunjukkan bahwa perlakuan berat benih dan media tanam serta interaksinya berpengaruh sangat nyata terhadap jumlah daun umur 30 hari setelah tanam. Data penelitian dapat dilihat pada Tabel 1 .

Hasil uji BNT taraf $5 \%$ terhadap parameter jumlah daun umur 30 hari setelah tanam pada perlakuan berat benih (B) menunjukkan bahwa perlakuan $b_{1}, b_{2}$ dan $b_{3}$ satu sama lainnya saling berbeda nyata.

Hasil uji BNT taraf $5 \%$ terhadap parameter jumlah daun umur 30 hari setelah tanam pada perlakuan media tanam (M) menunjukkan bahwa perlakuan $m_{1}, m_{2}$ dan $m_{3}$ satu sama lainnya saling berbeda nyata.

Hasil uji BNT taraf $5 \%$ terhadap tinggi bibit pada interaksi perlakuan berat benih dan media tanam (BxM) menunjukkan bahwa perlakuan $b_{3} m_{3}$ berbeda nyata dengan perlakuan $b_{2} m_{3}$, $b_{3} m_{2}, b_{1} m_{3}, b_{2} m_{2}, b_{3} m_{1}, b_{1} m_{2}, b_{2} m_{1}$ dan $b_{1} m_{1}$. Perlakuan $b_{2} m_{3}, b_{3} m_{2}$ dan $b_{1} m_{3}$ berbeda nyata dengan perlakuan $b_{2} m_{2}$, $\mathrm{b}_{3} \mathrm{~m}_{1}, \mathrm{~b}_{1} \mathrm{~m}_{2}, \mathrm{~b}_{2} \mathrm{~m}_{1}$ dan $\mathrm{b}_{1} \mathrm{~m}_{1}$. Perlakuan $\mathrm{b}_{2} \mathrm{~m}_{2}$ tidak berbeda nyata dengan perlakuan $b_{3} m_{1}$ dan $b_{1} m_{2}$, tetapi berbeda nyata dengan perlakuan $b_{2} m_{1}$ dan $b_{1} m_{1}$. Perlakuan $b_{3} m_{1}, b_{1} m_{2}, b_{2} m_{1}$ dan $b_{1} m_{1}$ satu sama lainnya saling tidak berbeda nyata.

\subsection{Jumlah Daun Bibit Kakao Umur 60 Hari Setelah Tanam}

Hasil sidik ragam menunjukkan bahwa perlakuan berat benih dan media tanam serta interaksinya berpengaruh sangat nyata terhadap jumlah daun umur 60 hari setelah tanam. Data penelitian dapat dilihat pada Tabel 1 .

Hasil uji BNT taraf $5 \%$ terhadap parameter jumlah daun umur 60 hari setelah tanam pada perlakuan berat benih (B) menunjukkan bahwa perlakuan $b_{1}, b_{2}$ dan $b_{3}$ satu sama lainnya saling berbeda nyata.

Hasil uji BNT taraf $5 \%$ terhadap parameter jumlah daun umur 60 hari setelah tanam pada perlakuan media tanam (M) menunjukkan bahwa perlakuan $\mathrm{m}_{1}, \mathrm{~m}_{2}$ dan $\mathrm{m}_{3}$ satu sama lainnya saling berbeda nyata.

Hasil uji BNT taraf $5 \%$ terhadap tinggi bibit pada interaksi perlakuan berat benih dan media tanam (BxM) menunjukkan bahwa perlakuan $\mathrm{b}_{3} \mathrm{~m}_{3}$ berbeda nyata dengan perlakuan $b_{3} m_{2}$, $\mathrm{b}_{2} \mathrm{~m}_{3}, \mathrm{~b}_{2} \mathrm{~m}_{2}, \mathrm{~b}_{3} \mathrm{~m}_{1}, \mathrm{~b}_{2} \mathrm{~m}_{1}, \mathrm{~b}_{1} \mathrm{~m}_{3}, \mathrm{~b}_{1} \mathrm{~m}_{2}$ dan $b_{1} m_{1}$. Perlakuan $b_{3} m_{2}$ tidak berbeda nyata dengan perlakuan $b_{2} m_{3}$, tetapi berbeda nyata dengan perlakuan, $b_{2} \mathrm{~m}_{2}, \mathrm{~b}_{3} \mathrm{~m}_{1}$, $\mathrm{b}_{2} \mathrm{~m}_{1}, \mathrm{~b}_{1} \mathrm{~m}_{3}, \mathrm{~b}_{1} \mathrm{~m}_{2}$ dan $\mathrm{b}_{1} \mathrm{~m}_{1}$. Perlakuan $\mathrm{b}_{2} \mathrm{~m}_{3}$ tidak berbeda nyata dengan perlkakuan $b_{2} m_{2}$ dan $b_{3} m_{1}$, tetapi berbeda nyata dengan perlakuan $b_{2} m_{1}, b_{1} m_{3}, b_{1} m_{2}$ dan $b_{1} m_{1}$. Perlakuan $b_{2} m_{2}$ dan $b_{3} m_{1}$ tidak berbeda nyata dengan perlakuan $\mathrm{b}_{2} \mathrm{~m}_{1}$, tetapi berbeda nyata dengan perlakuan $\mathrm{b}_{1} \mathrm{~m}_{3}, \mathrm{~b}_{1} \mathrm{~m}_{2}$ dan $\mathrm{b}_{1} \mathrm{~m}_{1}$. Perlakuan $\mathrm{b}_{2} \mathrm{~m}_{1}$ tidak berbeda nyata dengan perlakuan $\mathrm{b}_{1} \mathrm{~m}_{3}$, tetapi berbeda nyata dengan perlakuan $b_{1} m_{2}$ dan $b_{1} m_{1}$. Perlakuan $b_{1} m_{3}$ berbeda nyata dengan perlakuan $b_{1} m_{2}$ dan $b_{1} m_{1}$. Perlakuan $b_{1} m_{2}$ tidak berbeda nyata dengan perlakuan $b_{1} m_{1}$. 


\subsection{Jumlah Daun Bibit Kakao Umur 90} Hari Setelah Tanam

Hasil sidik ragam menunjukkan bahwa perlakuan berat benih dan media tanam berpengaruh sangat nyata, sedangkan interaksinya tidak berpengaruh nyata terhadap jumlah daun umur 90 hari setelah tanam. Data penelitian dapat dilihat pada Tabel 1.

Hasil uji BNT taraf $5 \%$ terhadap parameter jumlah daun umur 90 hari setelah tanam pada perlakuan berat benih (B) menunjukkan bahwa perlakuan $b_{3}$ tidak berbeda nyata dengan perlakuan $b_{2}$, tetapi perlakuan $b_{3}$ berbeda nyata dengan perlakuan $b_{1}$. Perlakuan $b_{2}$ berbeda nyata dengan perlakuan $b_{1}$.

Hasil uji BNT taraf $5 \%$ terhadap parameter jumlah daun umur 90 hari setelah tanam pada perlakuan media tanam (m) menunjukkan bahwa perlakuan $m_{3}$ berbeda nyata dengan perlakuan $\mathrm{m}_{2}$ dan $\mathrm{m}_{1}$. Perlakuan $\mathrm{m}_{2}$ tidak berbeda nyata dengan perlakuan $\mathrm{m}_{1}$.

\subsection{Diameter Batang Bibit Kakao Umur 30 Hari Setelah Tanam}

Hasil sidik ragam menunjukkan bahwa perlakuan berat benih dan media tanam berpengaruh sangat nyata, sedangkan interaksinya berpengaruh nyata terhadap diameter batang umur 30 hari setelah tanam. Data penelitian dapat dilihat pada Tabel 1 .

Hasil uji BNT taraf $5 \%$ terhadap parameter diameter batang umur 30 hari setelah tanam pada perlakuan berat benih (B) menunjukkan bahwa perlakuan $\mathrm{b}_{1}, \mathrm{~b}_{2}$ dan $b_{3}$ satu sama lainnya saling berbeda nyata.

Hasil uji BNT taraf $5 \%$ terhadap parameter diameter batang umur 30 hari setelah tanam pada perlakuan media tanam (M) menunjukkan bahwa perlakuan $\mathrm{m}_{1}, \mathrm{~m}_{2}$ dan $\mathrm{m}_{3}$ satu sama lainnya saling berbeda nyata.
Hasil uji BNT taraf $5 \%$ terhadap tinggi bibit pada interaksi perlakuan berat benih dan media tanam (BxM) menunjukkan bahwa perlakuan $b_{3} m_{3}$ berbeda nyata dengan perlakuan $b_{3} m_{3}$ tidak berbeda nyata dengan perlakuan $b_{3} m_{2}$ dan $b_{2} m_{3}$, tetapi berbeda nyata dengan perlakuan $b_{2} m_{2}, \quad b_{1} m_{3}, b_{1} m_{2}$, $b_{2} m_{1}, b_{3} m_{1}$ dan $b_{1} m_{1}$. Perlakuan $b_{3} m_{2}$ dan $\mathrm{b}_{2} \mathrm{~m}_{3}$ berbeda nyata dengan perlakuan $b_{2} m_{2}, b_{1} m_{3}, b_{1} m_{2}, b_{2} m_{1}, b_{3} m_{1}$ dan $b_{1} m_{1}$. Perlakuan $b_{2} m_{2}$ dan $b_{1} m_{3}$ tidak berbeda nyata dengan perlakuan $b_{1} m_{2}$ dan $b_{2} m_{1}$, tetapi berbeda nyata dengan perlakuan $\mathrm{b}_{3} \mathrm{~m}_{1}$ dan $\mathrm{b}_{1} \mathrm{~m}_{1}$. Perlakuan $\mathrm{b}_{1} \mathrm{~m}_{2}$ tidak berbeda nyata dengan perlakuan $b_{2} m_{1}$ dan $\mathrm{b}_{3} \mathrm{~m}_{1}$, tetapi berbeda nyata dengan perlakuan $\mathrm{b}_{2} \mathrm{~m}_{1}$, Perlakuan $\mathrm{b}_{2} \mathrm{~m}_{1}, \mathrm{~b}_{3} \mathrm{~m}_{1}$ dan $b_{1} m_{1}$ satu sama lainnya saling tidak berbeda nyata.

\subsection{Diameter Batang Bibit Kakao Umur 60 Hari Setelah Tanam}

Hasil sidik ragam menunjukkan bahwa perlakuan berat benih dan media tanam berpengaruh sangat nyata, sedangkan interaksinya tidak berpengaruh nyata terhadap diameter batang umur 60 hari setelah tanam. Data penelitian dapat dilihat pada Tabel 1 .

Hasil uji BNT taraf $5 \%$ terhadap parameter diameter batang umur 60 hari setelah tanam pada perlakuan media tanam (B) menunjukkan bahwa perlakuan $b_{3}$ berbeda nyata dengan perlakuan $b_{2}$ dan $b_{1}$. Perlakuan $b_{2}$ tidak berbeda nyata dengan perlakuan $b_{1}$.

Hasil uji BNT taraf $5 \%$ terhadap parameter diameter batang umur 60 hari setelah tanam pada perlakuan media tanam (M) menunjukkan bahwa perlakuan $\mathrm{m}_{1}, \mathrm{~m}_{2}$ dan $\mathrm{m}_{3}$ satu sama lainnya saling berbeda nyata.

\subsection{Diameter Batang Bibit Kakao Umur 90 Hari Setelah Tanam}


Hasil sidik ragam menunjukkan bahwa perlakuan berat benih dan media tanam berpengaruh sangat serta, sedangkan interaksinya tidak berpengaruh nyata terhadap diameter batang umur 90 hari setelah tanam. Data penelitian dapat dilihat pada Tabel 1 .

Hasil uji BNT taraf $5 \%$ terhadap parameter diameter batang umur 90 hari setelah tanam pada perlakuan media tanam (B) menunjukkan bahwa perlakuan $b_{3}$ berbeda nyata dengan perlakuan $b_{2}$ dan $b_{1}$. Perlakuan $b_{2}$ tidak berbeda nyata dengan perlakuan $b_{1}$.

Hasil uji BNT taraf $5 \%$ terhadap parameter diameter batang umur 90 hari setelah tanam pada perlakuan media tanam (M) menunjukkan bahwa perlakuan $\mathrm{m}_{1}, \mathrm{~m}_{2}$ dan $\mathrm{m}_{3}$ satu sama lainnya saling berbeda nyata.

Hasil sidik ragam menunjukkan bahwa perlakuan berat benih berpengaruh sangat nyata terhadap tinggi bibit umur 30 hari, umur 60 hari dan umur 90 hari setelah tanam, jumlah daun umur 30 hari, umur 60 hari dan umur 90 hari setelah tanam, diameter batang umur 30 hari, umur 60 hari dan umur 90 hari setelah tanam.

Adanya pengaruh yang nyata pada perlakuan berat benih pada pertumbuhan bibit kakao pada parameter tinggi bibit, jumlah daun dan diameter batang, keadaan ini disebabkan adanya perbedaan cadangan makanan yang dimiliki masingmasing perlakuan berat benih. Semakin berat benih maka semakin menghasilkan pertumbuhan bibit yang lebih baik, bila dibandingkan dengan benih yang beratnya lebih ringan.. Seperti dapat dilihat pada Tabel 1, bibit tertinggi, jumlah daun terbanyak dan diameter terbesar pada umur 30 hari, umur 60 hari dan umur 90 hari setelah tanam terdapat pada perlakuan $b_{3}$ (berat benih 18-20 g) yaitu 20,13 helai, sedangkan bibit terendah, jumlah daun paling sedikit dan diameter batang terkecil terdapat pada perlakuan $b_{1}$ (berat benih 7-13 g) yaitu : 17,69 helai.

Bibit yang berasal dari benih yang besar dapat mencapai ukuran awal bibit yang lebih besar. Selain itu lebih banyak terdapat kandungan nutrisi pada benih yang besar, dapat menyebabkan fotosintesis berlangsung lebih cepat, sehingga pertumbuhan dan kemampuan hidup bibit lebih baik. Oleh sebab itu benih yang besar dapat menghasilkan bibit yang lebih kompetitif dan toleran terhadap kondisi lingkungan yang tidak menguntungkan.

Pengaruh cadangan makanan, bahwa setelah berkecambah benih yang berukuran besar tetap mempertahankan proporsi cadangan makanan yang lebih besar yang selanjutnya dapat digunakan untuk pertumbuhan bibit, ketahanan hidupnya dan kemampuannya untuk pulih. Sehingga kelebihan cadangan makanan yang tersimpan di kotiledon akan meningkatkan kesempatan bibit untuk tumbuh pada kondisi lingkungan yang tidak menguntungkan. Selain itu juga berdasarkan pengamatan dilapangan bahwa benih yang besar memunculkan kecambah lebih cepat dan dapat hidup lebih baik pada kondisi tanah yang kurang subur atau miskin unsur hara. Sebagaimana dikemukakan oleh Sutopo (2002). bahwa ukuran biji mempengaruhi kemampuan biji untuk berkecambah, karena hal ini menunjukkan kandungan karbohidrat, protein, lemak, dan mineral. Bahan-bahan tersebut diperlukan sebagai bahan baku energi bagi embrio pada saat perkecambahan. Ukuran biji menunjukkan korelasi positif dengan kandungan protein dalam biji. Berat biji juga berpengaruh terhadap kecepatan pertumbuhan dan produksi. Biji yang besar/berat akan menghasilkan kecambah yang lebih besar, misalnya bunga matahari. Di dalam jaringan penyimpanannya benih memiliki karbohidrat, protein dan lemak serta 
mineral. Benih yang berukuran besar dan berat mengandung cadangan makanan yang lebih banyak bila dibandingkan dengan benih yang berukuran kecil. Berat benih berpengaruh terhadap kecepatan pertumbuhan dan produksi, karena berat benih menentukan besarnya kecambah pada saat permulaan dan berat tanaman pada saat panen.

Pengaruh media tanam terhadap pertumbuhan kakao, hasil sidik ragam menunjukkan bahwa perlakuan media tanam berpengaruh sangat nyata terhadap tinggi bibit umur 30 hari, umur 60 hari dan umur 90 hari setelah tanam, jumlah daun umur 30 hari, umur 60 hari dan umur 90 hari setelah tanam, diameter batang umur 30 hari, umur 60 hari dan umur 90 hari setelah tanam.

Media tumbuh sangat berperan penting terhadap kelangsungan pertumbuhan bibit. Media tanam berasal dari tanah top soil + pupuk kandang memberikan hasil pertumbuhan bibit yang lebih baik, seperti tinggi bibit, jumlah daun dan diameter batang, bila dibandingkan dengan jenis media tanam lainnya, yaitu tanah top soil + pasir dan tanah top soil + sekam padi. Keadaan ini disebabkan bahwa media tanam berupa campuran tanah top soil dan pupuk kandang, mampu memberikan kondisi pertumbuhan bibit kakao yang lebih baik, karena tanah top soil umumnya subur, karena banyak mengandung bahan organik, ditambah lagi dengan pupuk kandang yang juga memiliki keistimewaan yang banyak, yaitu mampu memperbaiki sifat fisik, kimia dan biologi tanh. Sehingga kondisi tanah menjadi baik dengan struktur yang gembur, mengandung unsur hara dan drainase dan aerasinya juga menjadi lebih baik, sehingga akar mampu berkembang dengan baik dan dapat menyerap unsur hara yang ada pada media tanam, sehingga bibit tumbuh lebih baik.
Sedangkan campuran media tanah top soil dan tanah pasir memberikan hasil pertumbuhann bibit yang kurang baik, karena sifat tanah pasir yang poros, daya pegang air dan unsur hara rendah, sehingga air dan unsur hara banyak yang terlarut kelapisan tanah yang lebih dalam, sehingga susah dijangkau oleh akar. Sebagaimana dikemukakan oleh Marsono dan Sigit (2003), bahwa pupuk kandang mampu memperbaiki struktur tanah, meningkatkan ketersediaan air tanah dan menambah unsur hara di dalam tanah.

Interaksi perlakuan terhadap pertumbuhan bibit kakao, hasil sidik ragam menunjukkan bahwa interaksi perlakuan berat benih dan media tanam tidak berpengaruh nyata terhadap tinggi bibit umur 60 hari dan umur 90 hari setelah tanam, jumlah daun umur 90 hari setelah tanam, dan diameter batang umur 60 hari dan 90 hari setelah tanam. Berpengaruh nyata terhadap diameter batang umur 30 hari setelah tanam. Berpengaruh sangat nyata terhadap tinggi bibit umur 30 hari setelah tanam, jumlah daun umur 30 hari dan umur 60 hari setelah tanam.

Interaksi antara perlakuan berat benih dan media tanam memberikan pengaruh yang nyata pada beberapa data penelitian yang diamati. Interaksi perlakuan berat benih 18-20 g $\left(b_{3}\right)$ dan media tanam tanah top soil + pupuk kandang cenderung memberikan hasil yang lebih baik, dibandingkan perlakuan lainnya, keadaan ini disebabkan bahwa dengan asal benih yang lebih berat dan media tanam yang kondisinya baik, akan menghasilkan pertumbuahn bibit yang lebih baik pula, seperti tinggi bibit, jumlah daun dan diameter batang. 


\section{KESIMPULAN}

Berdasarkan hasil penelitian dapat diambil beberapa kesimpulan : 1) Perlakuan berat benih berpengaruh sangat nyata terhadap tinggi bibit umur 30 hari, umur 60 hari dan umur 90 hari setelah tanam, jumlah daun umur 30 hari, umur 60 hari dan umur 90 hari setelah tanam, diameter batang umur 30 hari, umur 60 hari dan umur 90 hari setelah tanam. Bibit tertinggi terdapat pada perlakuan $b_{3}$ (berat benih $18-20 \mathrm{~g}$ ) yaitu : $20,59 \mathrm{~cm}$, sedangkan bibit terendah terdapat pada perlakuan $b_{1}$ (berat benih 7-13 g) yaitu : $17,69 \mathrm{~cm}$. 2) Perlakuan media tanam berpengaruh sangat nyata terhadap tinggi bibit umur 30 hari, umur 60 hari dan umur 90 hari setelah tanam, jumlah daun umur 30 hari, umur 60 hari dan umur 90 hari setelah tanam, diameter batang umur 30 hari, umur 60 hari dan umur 90 hari setelah tanam. Jumlah daun terbanyak terdapat pada perlakuan $\mathrm{m}_{3}$ (tanah top soil + sekam padi) yaitu : 20,64 helai, sedangkan jumlah daun paling sedikit terdapat pada perlakuan $\mathrm{m}_{1}$ (tanah top soil + pasir) yaitu : 18,22 helai. 3) Interaksi perlakuan berat benih dan media tanam tidak berpengaruh nyata terhadap tinggi bibit umur 60 hari dan umur 90 hari setelah tanam, jumlah daun umur 90 hari setelah tanam, dan diameter batang umur 60 hari dan 90 hari setelah tanam. Berpengaruh nyata terhadap diameter batang umur 30 hari setelah tanam. Berpengaruh sangat nyata terhadap tinggi bibit umur 30 hari setelah tanam, jumlah daun umur 30 hari dan umur 60 hari setelah tanam.
Interaksi yang terbaik adalah $b_{3} m_{3}$ untuk parameter tingi bibit kakao pada umur 90 hari setelah tanam yaitu : $25,28 \mathrm{~cm}$ dan jumlah daun terbanyak umur 90 hari setelah tanam yaitu : 21,38 helai.

\section{DAFTAR PUSTAKA}

Abidin Z. 1997. Dasar Pengetahuan Ilmu Tanman. Angkasa. Bandung.

Agoes D. 1994. Aneka Jenis Media Tanam dan Penggunaannya. Penebar Swadaya. Jakarta.

Chairil, S.M. 2000. Pengaruh Media Tanam dan Hormon Rootone F Terhadap Pertumbuhan Stek Batang Gmelina arborea Ross Dalam Green House. Pt. OTP. Muara Ancalong. Kabupaten Kutai Timur.

Harjadi, S.S. Pengantar Agronomi. Gramedia Pustaka Utama. Jakarta.

Hatta, S. 1992. Coklat, Pengolahan Hasil dan Aspek Ekonominya. Kanisius. Yogyakarta.

Hanafiah, P. 2003. Rancangan Percobaan, Teori dan Aplikasi. Gramedia. Jakarta.

Kartasapoetra, G. 1986. Teknologi Benih. Rineka Cipta, Jakarta

Marsono dan Lingga, P. 2003. Petunjuk Penggunaan Pupuk. Penebar Swadaya. Jakarta.

Novizan. 2002. Petunjuk Pemupukan Efaktif. Agromedia Pustaka. Jakarta. 
Qamara, W.M dan A. Setiawan. 1995. Pengantar Produksi Benih. Raja Grapindo. Persada. Jakarta.

Sarief, E.S. 1986. Ilmu Tanah Pertanian. Pustaka Buana. Jakarta.

Sutarmi, S. 1983. Botani Umum Jilid II. Angkasa. Bandung.
Sutopo, L. 2004. Teknologi Biji. Gravindo Persada. Jakarta.

Winarno, M., H. Sunarjono, Ismiyanti dan S. Kusuma. 1996. Teknik Perbanyakan Cepat Buah-Buahan Tropik. Pusat Penelitian dan Pengembangan Hortikultura. Jakarta. 